International Journal of Social Sciences and Humanities
Available online at http://sciencescholar.us/journal/index.php/ijssh
Vol. 2 No. 3, December 2018, pages: 33 44
e-ISSN: 2550-7001, p-ISSN: 2550-701X
https://doi.org/10.29332/ijssh.v2n3.194

\title{
Local Wisdom Philosophy of Labo Maja Dahu for Bima Community
}

\author{
Mustamin a, Junaidin ${ }^{b}$
}

Article history: Received 8 April 2018, Accepted: 30 August 2018, Published: 11 September 2018

\section{Correspondence Author ${ }^{\text {a }}$}

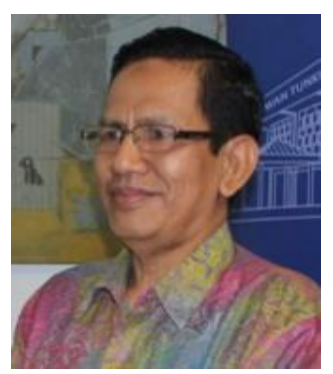

Keywords

Bima;

Character education;

Expression;

Maja labo dahu;

Philosophy;

\begin{abstract}
Maja Labo Dahu, a philosophical phrase that contains a broad meaning. If the phrase is taken literally Maja Labo Dahu means shame with fear this will give meaning and psychological impact that is not desired by the expression itself. Such understanding and meaning will only dwarf the mind, shut down the initiative and drain the ideals to move forward to achieve the coveted hopes. The phrase Maja Labo Dahu is a symbol that is pronounced with three words that always the application of both can't be separated and separated from each other because mutually give influence to the formation of positive attitude. By that is also called as a philosophical phrase which contains broad meaning can serve as guidelines and life orientation. The purpose of this research is to study the meaning of Maja Labo Dahu's philosophy of Bima has a logical meaning to character education in school. To achieve this goal the authors use the qualitative design and choose the content analysis approach. Based on the results of data analysis, it can be concluded that: a verse contains definitions, purposes, functions, and principles of guidance and verses that contain the value of personal and social guidance.
\end{abstract}

e-ISSN: 2550-7001, p-ISSN: 2550-701X ${ }^{\odot}$ Copyright 2018. The Author. SS Journals Published by Universidad Técnica de Manabí. This is an open-access article under the CC BY-SA 4.0 license (https://creativecommons.org/licenses/by-sa/4.0/) All rights reserved.

\section{Contents}

Abstract 33

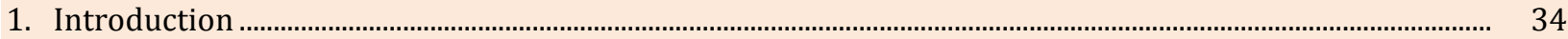

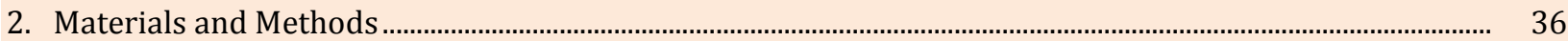

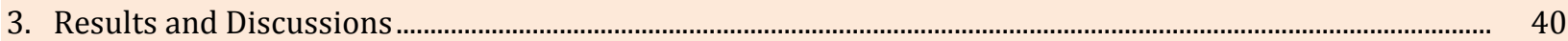

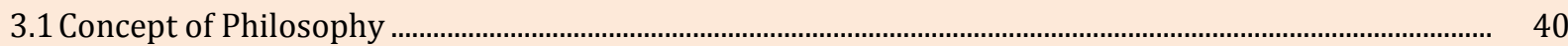

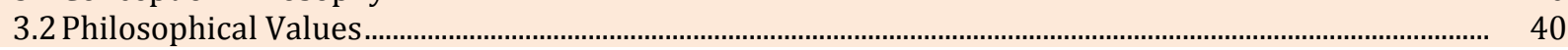

a Muhammadiyah University of Mataram, West Nusa Tenggara, Indonesia

b Muhammadiyah University of Mataram, West Nusa Tenggara, Indonesia 
3.3 Implications of the Meaning of Philosophy values in Social-Personal Guidance ......................................... 40

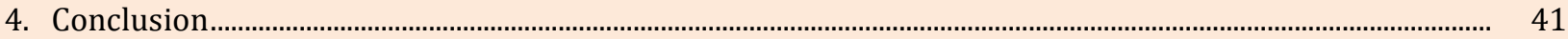

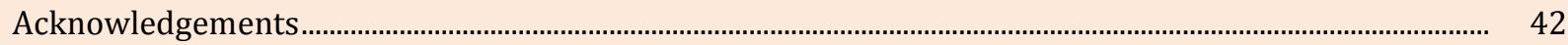

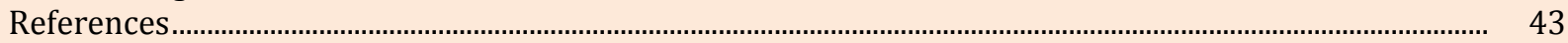

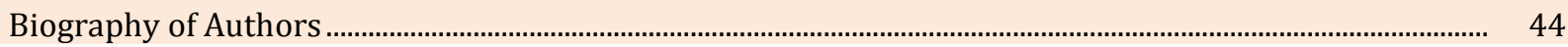

\title{
1. Introduction
}

West Nusa Tenggara has of two large islands (Sumbawa Island and Lombok Island) besides other small islands. The island is inhabited by three tribes (Mbojo (Bima), Samawa (Sumbawa) and, Sasak (Lombok). These tribes are the majority of the ethnic community in West Nusa Tenggara. The Bima and Sumbawa tribes inhabit Sumbawa Island while the Sasak tribe spread throughout Lombok Island (Rijal, 2016).

Similar with other universal tribes and ethnicity, the three tribes in NTB have a different culture but each has noble values entrenching in the life it's of society. The Bima tribe has the cultural value system namely Maja Labo Dahu, the Sumbawa tribe has a culture named Sabalong Samalewa culture, and the Sasak tribe is famous for its culture named Patut Patuh Patju. In this case, the study was focused on the culture of Maja Labo Dahu from the Bima tribe.

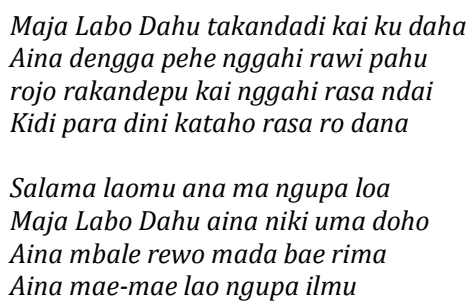

Maja Labo Dahu is an ideal cultural value system that is abstract, meaning that Maja Labo Dahu is a view of life used as a guideline in thinking, acting and communicating in the community. Maja Labo Dahu is abstract, because it is an ideal cultural value system as a view of life (Aziz et al., 2016), H. Zainal (one of the historical figures) of the Bima community said that "Maja Labo Dahu" is a powerful weapon in wading waves of ark of life its people both in their own country and overseas, as he stated the following philosophy;

\author{
Malu dan Takut kita jadikan senjata (Shame and Fear, we use as weapons) \\ Jangan berhenti ucap, bicara berbuat bukti (Don't stop saying, speak and prove) \\ Tegur dan ingatkan dengan bahasa sendiri (Rebuke and remind yourself by your own language) \\ Berdiri yang tegak membangun negeri (Standing bravely in building the country) \\ (dalam bahasa Indonesia) \\ Selamat jalan anak yang mencari ilmu (Goodbye children who seek knowledge) \\ Malu dan takut jangan setiap rumah duduk (Be shame and fear, do not sit in every house) \\ Jangan sering bergaul yang tidak berjejak (Don't hang out often with who don't walk) \\ Jangan main-main pergi mencari ilmu (Don't mess around, go and seek knowledge) \\ (dalam bahasa Indonesia)
}

Maja Labo Dahu can be seen in the behavior of the Bima community. Maja Labo Dahu is more symbolic and meaningful. The Bimanese in the rural area, for example, have the view that Maja Labo Dahu means dou (human) which has properties that are different from other creatures. Even though the dou has other human characteristics, it also has animalistic characteristics. In their view, since a human can distinguish good and bad thing, people who can apply their human characteristics or who have Maja Labo Dahu are called dou (humans). For example, a person who is successful in his education, his work, or business is claimed that they become a human (Jasman, 2017).

Maja Labo Dahu, a philosophical expression that has a broad and wide meaning. If this expression is literally interpreted, Maja Labo Dahu means to be ashamed of fear that will give meaning and psychological impact not desired by the expression itself. Such understanding and meaning will only dwarf the mind, turn 
off the initiative and drain the aspiration to move forward to achieve the desired hope (Nurhasanah, 2017). The phrase Maja Labo Dahu is a symbol that is pronounced in three words in which its application cannot be separated from one another, because of the effect on the formation of a positive attitude. Therefore, it is also called a philosophical expression that possesses broad meaning.

In June 2017 an interview was conducted with H. Zainal (historian) who said: "in the language of Religion, Maja Labo Dahu means Al-hayaa'u wat taqwaminal Iman meaning that shame and fear of Allah are part of the Faith". Maja Labo Dahu's expression is in line with the religious breath that is applied carefully to speak, supervised in action and high enthusiasm to realize plans and programs. People who are consistent and responsible is a manifestation of the nature of Maja Labo Dahu. Likewise, an actual picture of Maja Labo Dahu, the pre-survey results conducted by researchers in June 2017, by conducting interviews with Bima cultural figures, Mr. Ismail claimed that:

\begin{abstract}
"Bagi orang Bima merupakan norma adaptasi yang harus dipegang sebagai "Fu'u mori ro woko"(tiang atau pedoman hidup). Maja Labo Dahu adalah system nilai yang sarat dengan nilai Iman dan Takwa, kebajikan, martabat, dan harga diri yang selalu menjadi rujukan dalam bertindak. Orang yang tidak mematuhi orangtuanya termasuk orang yang kurang Maja Labo Dahunya".

"For the Bimanese, it is an adaptation norm that must be held as" Fu'u mori ro woko "(pillar or life guide). Maja Labo $D a h u$ is a value system that is full of faith and piety, virtue, dignity, and self-esteem that become a reference in acting. People who do not obey their parents are said people who are less Maja Labo Dahunya".
\end{abstract}

Therefore, Maja Labo Dahu became the deepest part of the person of Bima Dou Mbozo which is prestigious, respected and needed to be maintained. One of the efforts made by the kings of Bima and community leaders in the past so that the existence of Maja Labo Dahu in the Bima community remains a guide or guide in thinking, acting, and communicating is to actualize moral messages in the form of Philosophy (guidelines) (Nurhasanah, 2017). Philosophy is advice, precept, mandate, or exhortation that is delivered in spoken or written to its citizens for generations. That is why the philosophy is maintained and respected to be used as a way of life in society. Therefore, if a person or group of people violate the values of Maja Labo Dahu in Philosophy, they will be excluded from the association of their family, relatives, groups, and society. Based upon this, the philosophy is a moral calling to preserve the culture of Maja Labo Dahu that has been inherited from generation to generation.

By paying attention to the main philosophy that is moral virtue messages, it seems that Philosophy and pantun (traditional poetry) can function as guidelines or behavioral guidelines, especially for Bima cultural actors or followers (Endraswara, 2015). Based on the study above, under the shelter of education, Philosophy has the potential to be a source of learning material, especially for personal social guidance. As guidance material, the delivery of Philosophy to clients (students who are problematic) is expected to be able to change behavior in both interpersonal and social relationships.

In modern society, referring to Shipman, the main function of education is summed in three ways: the first is socialization, as a vehicle for the integration of students into a dominant group or national values. The second is school meaning that the preparation of students to occupy certain socio-economic positions in the community with the provision of job and professional qualifications. The third is education defined as the creation of elite groups expected to contribute greatly to the continuation of the modernization program. Schools turned out to be not neutral or value-free. He is already regarded as the best vehicle for the inheritance and preservation of values which are in fact that is only official, happening, sanctioned and must even be taught in all schools with the same official interpretation (Hardianta et al., 2015).

Culture, education, and religion are three fields related to each other. All of these three elements relate to the level of values that are strongly important for humans in various aspects of their lives. Culture generally includes noble values that traditionally become role models for society (Aziz et al., 2016). Besides, to cover the process of transfer and transmission of knowledge, education is also a very strategic process in instilling values in the framework of civilizing human children. Meanwhile, religion also contains teachings about various noble and noble values for humans to achieve humanity and culture.

However, the three sources of value that are important for life at certain times cannot be fully functional in the formation of individuals and communities with character, justice, and respect. Culture, education, and even religion may experience disorientation due to rapid changes that have broad impacts such as

Mustamin, -, \& Junaidin, -. (2018). Local wisdom philosophy of labo maja dahu for bima community. International Journal of Social Sciences and Humanities, 2(3), 33-44. https://doi.org/10.29332/ijssh.v2n3.194 
industrialization, urbanization, modernization, and globalization. The condition of people's character today, from the international level to the personal level of individuals, especially our nation, seems to be disoriented (Indah et al., 2015). Therefore, hopes and appeals from various circles for the redevelopment of human nature or character are increasingly increasing and loud.

The implementation of the character education process in Indonesia that takes into account the local culture, namely trust, family values, paternalistic, and beliefs (Hadi, 2017). In line with the opinion stated that the implementation of guidance in schools could not ignore the local culture and its influence in the guidance process. The philosophy contains values embraced by the Bima community, reviewed theoretically, and therefore qualified as social-personal guidance material. As a part of efforts to improve education services oriented to Indonesian culture, various trials have been conducted in several regions in Indonesia such as applying sodong (sodoran) (a traditional play shown in form of battle between soldiers by using an equipment called sodor) and dongengan (storytelling)) in technic of group education. From the trial, Ridjal concluded that playing sodong is a group education technique to reduce the frequency of unwanted social adjustment behavior (Gepu, et al., 2018; Wirawan, 2018; Subagiasta, et al., 2018).

Based on the aforementioned background of the problem, it is deemed necessary to conduct a study of the Philosophy of Maja Labo Dahu in the Bima Community and its Implications for Material Development for Character Education. This effort is applied to provide enrichment and socialization in the School so that teachers can develop their concepts and skills by providing learning services as professional services.

\section{Materials and Methods}

The object of the study in this study is the philosophy (message) conveyed by the Kings, parents or wise people in the past. Philosophy is the teachings of the Bimanese that are used to build and foster the personality of children, grandchildren, and citizens so that they can become dou (humans) and maintain their dignity. This philosophy has been compiled in various books, including the Bima Falsafah Kerajaan Bima (The Philosophy of Kingdom Bima) compiled by Henry Chambert-Loir, Nusantara Manuscripts and Documents (1982) and the Bimaneesche Texten book compiled by J.C.G. Jongker (1894).

The approach used in this research is the content analysis approach (hermeneutics). This refers to the basic concept of Krippendorff (1981) arguing that to understand and explain the symbolic messages, it requires complex and systematic information processes that are employed by other research methods. The content analysis method is a special method developed to study the symbolic phenomena contained in messages. In line with the research objectives, the data analysis is directed to identify the value of Philosophy and its relation to social-personal guidance. To meet these objectives, data analysis techniques are employed with the following procedures:

The data or philosophy that has been identified is given a password, page number (according to the original source), and the serial number. Data obtained from the book entitled "Falsafah Kerajaan Bima" (Philosophy of Kingdom Bima) was given SKB password, while data obtained from the book entitled Bima Neesche Texten was coded as BNT. Data from these two books are then given page numbers and serial numbers. This presentation and numbering are shown in the following example.

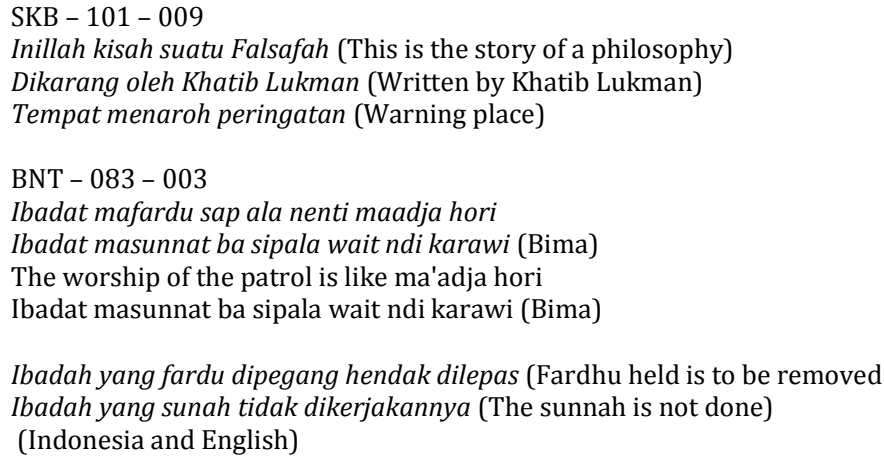

Ibadah yang fardu dipegang hendak dilepas (Fardhu held is to be removed Ibadah yang sunah tidak dikerjakannya (The sunnah is not done) (Indonesia and English) 
Explanation:

SKB and BNT are the codes of the book entitled "Falsafah Kerajaan Bima" (Philosophy of Kingdom Bima) and the book entitled Bima Neesche Texten, numbers 101 and 083 are page numbers, and the numbers 009 and 003 indicate the serial number.

Table 1

Table of Value Category Work and Philosophy contents

\begin{tabular}{|c|c|c|c|}
\hline No & $\begin{array}{c}\text { Categories of } \\
\text { Philosophical Values }\end{array}$ & Philosophical message & Sandi \\
\hline 1. & $\begin{array}{l}\text { Nggahi Poda } \\
\text { (Truth) }\end{array}$ & $\begin{array}{l}\text { - Not lying } \\
\text { - Prove the words said } \\
\text { - The words are the source of } \\
\text { goodness and badness } \\
\text { - Watch the words } \\
\text { - The words should not be } \\
\text { exaggerated }\end{array}$ & $\begin{array}{l}\text { SKB-101-009 } \\
\text { SKB-113-082 } \\
\text { BNT-088-056 } \\
\text { SKB-113-028 } \\
\text { BNT-089-069 }\end{array}$ \\
\hline 2. & $\begin{array}{l}\text { Rombo Ade } \\
\text { (Integrity) }\end{array}$ & $\begin{array}{l}\text { - } \text { Be free from sin } \\
\text { - } \text { Be honest with yourself } \\
\text { - } \text { Be honest with others } \\
\text { - } \text { Be honest with God }\end{array}$ & $\begin{array}{l}\text { SKB-143-260 } \\
\text { BNT-048-017 } \\
\text { BNT-087-048 }\end{array}$ \\
\hline 3. & Rundu (Motivation) & $\begin{array}{l}\text { - Encourage people to always do } \\
\text { the good things } \\
\text { - Encourage others to not easily } \\
\text { satisfied with achievements } \\
\text { - Encourage others to be earnest } \\
\text { in struggling }\end{array}$ & $\begin{array}{l}\text { SKB-100-003 } \\
\text { SKB-100-004 } \\
\text { SKB-100-005 } \\
\text { SKB-101-008 }\end{array}$ \\
\hline 4. & $\begin{array}{l}\text { Kacoi Angi } \\
\text { (respect) }\end{array}$ & $\begin{array}{l}\text { - Doing mutual warns } \\
\text { - Fate } \\
\text { - Help each other } \\
\text { - Forgive each other } \\
\text { - Respect each other (mutual } \\
\text { respect) }\end{array}$ & $\begin{array}{l}\text { BNT-088-055 } \\
\text { SKB-155-330 } \\
\text { SKB-177-461 } \\
\text { SKB-143-256 }\end{array}$ \\
\hline 5. & $\begin{array}{l}\text { Nggahi Rawi Pahu } \\
\text { (responsibility) }\end{array}$ & $\begin{array}{l}\text { - Obey the teachers' words } \\
\text { - Being brave in doing the good } \\
\text { things } \\
\text { - Obey the advice and command } \\
\text { - Keep holding the truth } \\
\text { - Being brave to take a risk } \\
\text { - Being brave to do the right } \\
\text { things }\end{array}$ & $\begin{array}{l}\text { SKB-129-178 } \\
\text { SKB-142-252 } \\
\text { SKB-142-259 } \\
\text { SKB-164-381 } \\
\text { BNT-084-016 } \\
\text { SKB-166-391 }\end{array}$ \\
\hline 6. & $\begin{array}{l}\text { Tohompara nahu sura } \\
\text { dou marimpa } \\
\text { (mutual help) }\end{array}$ & $\begin{array}{ll}\text { - } & \text { Help others who cannot afford } \\
\text { - } & \text { Help each other } \\
\text { - } & \text { Prioritize those who most need } \\
\text { help } \\
\text { - } \\
\text { - } & \text { Helping by praying by energy or efforts }\end{array}$ & $\begin{array}{l}\text { SKB-106-040 } \\
\text { SKB-107-049 } \\
\text { SKB-139-233 } \\
\text { SKB-116-100 } \\
\text { SKB-144-264 }\end{array}$ \\
\hline 7. & Tenggo (Tenacity) & $\begin{array}{l}\text { - Strongly believe in religion } \\
\text { - Strongly keep the promise } \\
\text { - Being optimistic in reaching } \\
\text { the dream }\end{array}$ & $\begin{array}{l}\text { SKB-112-079 } \\
\text { SKB-126-159 } \\
\text { SKB-144-261 } \\
\text { SKB-145-270 } \\
\text { SKB-145-267 }\end{array}$ \\
\hline
\end{tabular}

Mustamin, -, \& Junaidin, -. (2018). Local wisdom philosophy of labo maja dahu for bima community. International Journal of Social Sciences and Humanities, 2(3), 33-44. https://doi.org/10.29332/ijssh.v2n3.194 


\begin{tabular}{|c|c|c|c|}
\hline 8. & $\begin{array}{l}\text { Wii Weki ndei Ruma } \\
\text { (defencelessness } \\
\text { God) }\end{array}$ & $\begin{array}{ll}\text { - } & \text { Believe in fate } \\
\text { - } & \text { Trying and making efforts } \\
& \text { while praying } \\
\text { - } & \text { Begging for forgiveness } \\
\text { - } & \text { Begging for safety } \\
\text { - } & \text { Death } \\
\text { - } & \text { Defencelessness }\end{array}$ & $\begin{array}{l}\text { SKB-116-103 } \\
\text { SKB-117-104 } \\
\text { SKB-117-105 } \\
\text { SKB-146-274 } \\
\text { SKB-106-038 } \\
\text { SKB-167-402 }\end{array}$ \\
\hline
\end{tabular}

Source: Buku Falsafah Kerajaan Bima dan Bima Neesche Texten, 1983

\section{Theory}

Philosophy for the Bima community is noble values that serve as guidelines and guidance for people's lives and is one of the cultural values influencing the personality of the Bima community. The philosophy conveyed by parents or people to the children, grandchildren, and their families is used as an exhortation that is always remembered, obeyed, and carried out with full responsibility and confidence. The strong belief of Bima people to the philosophy of wisdom, especially the old people, causes them to maintain and cultivate it in all aspects of their lives as an identity in establishing Maja Labo Dahu. In this study, the researcher focused on the problems described in the following questions:

a) What values are contained in the Philosophy of Maja Labo Dahu?

b) Do the values and content of the message involved in the Philosophy of Maja Labo Dahu in Bima community have logical meaning towards the character education at school?

c) How do the values of the philosophy of Maja Labo Dahu in Bima community impact on the learning material for character education at school?

In general, the purpose of this research is to study whether or not the values of the philosophy of Maja Labo Dahu have logical meaning towards character education in school.

Specifically, this study aims at:

a) Identifying the values of the Philosophy of Maja Labo Dahu in Bima Community

b) Finding the values and content of messages in the Philosophy of Maja Labo Dahu in Bima Community that have a logical meaning towards character education in school.

c) Using the values and content of the Philosophy of the message of Maja Labo Dahu message in Bima Community as the implication on the development of learning material for a character in schools.

\section{Character Education (Moral, Value, Religion and Citizenship)}

The meaning of education is basically an effort (process) of the transformation of knowledge and values to the subject of the education including the totality of human aspects to enliven their awareness, attitude, and critical actions towards all phenomena that occur around him. According to Peter McLaren, "Critical education states that the position of pedagogical areas in the form of universities, public schools, museums, art galleries or other places must have a vision that does not contain individuals who are adaptive to the world of oppressive social relations but dedicated to transforming such conditions." The character education and character building in schools are solely carried out through learning and knowledge. In general, studies of values usually include two main areas, aesthetics and ethics (or character and morals) (Hadi, 2017). Aesthetics refers to things and justification of what people see as "beautiful" or what they like. Meanwhile, ethics refers to things and justification of appropriate behavior based on standards that are believed and applied in society, whether those originating from religion, customs or conventions, and so on. In addition, those standards are moral values of good and bad action or behavior (Hardianta et al., 2015)

At the international level, peace is far from being realized. Even our day is still witnessing, conflict, violence, and the war in various parts of the earth. Violence and murder continue to occur, for example, in the 
Middle East between Israel and Palestine, Iraq and Afghanistan, which continue to be turbulent due to the occupation of America, Britain and its sustainable allies, even though democracy seems to get its roots in these countries. Various violations that cost lives and property are related to the persistence of "structural violence" at the international level both in the political, economic, military, technological, information and socio-cultural fields. As a result, ultimate peace has not or has never been successfully realized.

Pada level bangsa (nation) Indonesia, seperti terlihat dalam sedikit contoh di atas, harus segera diakui bahwa negara kita tidaklah sepenuhnya dalam keadaan in order, bahkan sebaliknya dalam banyak segi masih dalam kondisi disorder. Dalam beberapa tahun terakhir, Indonesia hanya mampu mengatasi krisis ekonomi dan politik secara relatif sangat lamban. Politik memang kelihatan relatif lebih stabil sejak masa Presiden Megawati Soekarnoputri hingga hampir berakhirnya masa Presiden Jokowidodo sekarang ini, setelah hiru-biru berbagai kontroversi pada masa Presiden Abdurrahman Wahid.

\begin{abstract}
At the national level of Indonesia, it was immediately recognized that our country was not completely in an in-order state; on the contrary, in many respects, it is still disordered. In recent years, Indonesia has only been able to overcome the economic and political crisis relatively slowly. Politics indeed seems relatively more stable since the government era of President Megawati Soekarnoputri until the end of President Jokowidodo (current), after the commotion of various controversies during the government period of President Abdurrahman Wahid.
\end{abstract}

Meanwhile, economic conditions have not fully improved either; even though built-up-luxury cars are increasingly crossing the highway. A life is extremely contrast. Even worse, Indonesia is still threatened by social and political disintegration both vertically and horizontally. The seeds of disintegration and conflicts and social violence continue to grow because of various factors: political, social, cultural, and religious issues that are still vulnerable (Harianja and Waluyo, 2017).

The crisis of culture and religion, talks and discourses about rebuilding the character to revitalize the resilience of the nation have filled the public space since the fall of President Soeharto from his power in 1998 until now (more than a decade). Dramatic, rapid and long-term changes in political life which in turn also lead to social and cultural disorientation gave rise to discourses and hopes about the need for the re-establishment of national character; the first Indonesian President's statement, Soekarno (1959) about 'nation and character building' again found its relevance. The end of the power of the New Order, along with the emergence of a crisis in various aspects of the life of the nation has also caused a crisis in the character and resilience of the nation. The swift flow of globalization that carries various forms and expressions of global culture is an important additional factor that results in the erosion or decrease of the nation's character to progress more quickly and broadly. A further consequence, the crisis of the nation's character leads to disruption and dislocation in the social and cultural life of the nation so that it threatens the integrity and resilience of the nation as a whole.

The wider community environment clearly has a major influence on the success of planting aesthetic and ethical values for character building. Based on the Islamic perspective, according to Quraish Shihab (1996), the social situation with the system of values adopted influences the attitude and perspective of society as a whole. If their value and outlook system are limited to "now and here", then their efforts and ambitions are limited now and here too.

\title{
Values in Character Education
}

If character education involves various kinds of value elements (religious values, moral values, general values, and citizenship values), the main problem arises with regard to the cultivation of values in character education, especially related to the choice of values (Endraswara, 2015). If it is seen from its main purpose, especially from the sociological and political perspective, character education is primarily the interests of the state. This is because the state has an interest so that individuals who are immature can have good preparation when they are demanded to enter the political life of the community normally and naturally without difficulty. Without preparation to become citizens, individuals who are immature will experience difficulties and do not understand their rights and obligations as citizens; therefore, they have the potential to be a nuisance to the dynamics and stability of society.

In line with Komensky (1980), idea stating that students should be taught the whole virtue without excluding it. This is the basic principle of character education because school is an institution that can

Mustamin, -, \& Junaidin, -. (2018). Local wisdom philosophy of labo maja dahu for bima community. International Journal of Social Sciences and Humanities, 2(3), 33-44. https://doi.org/10.29332/ijssh.v2n3.194 
maintain the life of values of a society so that it is not just any way of acting, behavior patterns, which are taught in schools, but values that increasingly bring the process of culture and it is people who are allowed to enter the investment of value at school. These values are taken as an outline only, they are open, they can still be added to other values that are relevant to the situation of the educational institutions where each individual works.

\section{Results and Discussions}

\subsection{Concept of Philosophy}

The first finding of this study shows that as a concept, the Philosophy of Maja Labo Dahu in Bima Community contains the meaning, purpose, function, and principles of building character. The definition of Philosophy, in general, is the advice, teachings or precept, mandate, or will or exhortation of kings, Bimanese, Wise people, community leaders, and parents which are delivered orally and in writing to generations, so that they can think, act, and communicate well in the community. The aim of Philosophy is to advise children, grandchildren, family, and relatives to not make things that the community does not like. The philosophy function is divided into two: preventive and corrective. Preventive functions are in the form of personal coaching to children, grandchildren, and family/relatives. Correctively, the philosophy serves to advise citizens who make mistakes so that they do not do the same thing in the future. Meanwhile, the philosophy principle is as follows: (1) Philosophy must be given to people who are in conflict with others in order to reconcile it, (2) Community leaders or people who are not allowed to allow a protracted mistake because they bear the consequences (3) Philosophy is not compelling.

Based on these findings, the Philosophy of Maja Labo Dahu Bima Community has a logical meaning towards character education in schools based on concepts: understanding, purpose, function, and principles (Shartzer and Stone, 1981). In general, character education is defined as a process of providing assistance to individuals on a continuous and systematic basis, carried out by a counselor who has received special training for it. Based on this understanding, the delivery of the Philosophy can also be interpreted as an effort to provide assistance/advice to individuals and community groups.

\subsection{Philosophical Values}

This study discovered eight Philosophy values, namely: (1) Nggahi Poda (Truth), (2) Rombo Ade (integrity), (3) Rundu (Motivation), (4) Kacoi Angi (mutual respect), (5) Nggahi Rawi Pahu (Responsibility), (6) Tohompara nahu sura dou marimpa (mutual help), (7) Tenggo (tenacity), (8) Wii Weki ndei Ruma (defencelessness to God). The way to use the philosophy values in the learning material is by including the values of truth, integrity, motivation, responsibility, and defencelessness to God into topics of learning material for education in schools and values of mutual respect, responsibility, and mutual help to become topics of learning material for social guidance.

\subsection{Implications of the Meaning of Philosophy values in Social-Personal Guidance}

The third findings of this study are philosophical values, namely: This study discovered eight Philosophy values, namely: (1) Nggahi Poda (Truth), (2) Rombo Ade (integrity), (3) Rundu (Motivation), (4) Kacoi Angi (mutual respect), (5) Nggahi Rawi Pahu (Responsibility), (6) Tohompara nahu sura dou marimpa (mutual help), (7) Tenggo (tenacity), (8) Wii Weki ndei Ruma (defencelessness to God). Each of these values contains various contents or message of philosophy (advice). Broadly speaking, the implications between the values of the philosophy of Maja Labo Dahu in character education goals in school, personal social can be explained as follows. The values of Nggahi Poda and Rombo Ade are included in the objective component of having selfawareness; the value of Nggahi Poda dan rombo ade included in the component that develops a positive attitude; the values of Kacoi Angi and Tahompara Nahu Sura Dou Marimpa are included in the objective 
component of being able to respect others; the values of Nggahi Poda, Rombo Ade, Tenggo and Nggahi Rawi Pahu are included in the objective component with responsibility; the value of rundu, Kacoi Angi, and Tohompara Nahu Sura Dou Marimpa is included in the component of objectives to develop inter-personal relations; the value of Nggahi Poda, Rombo Ade, Rundu, Kacoi Angi, Tahompara nahu sura dou marimpa and Wii Weki ndei Ruma are included in the objective component to resolve conflicts; the value of Nggahi Poda, rombo ade dan wii weki ndai Ruma is included in the objective component of making good choices; and the value of nggahi poda, rombo ade, tenggo and wii weki ndai Ruma is included in the objective component to make good decisions.

Based on these findings, it seems that local cultural values can be used as a material for social-personal guidance services. These findings also provide a justification for the opinion of Munandir (2012) who said that the development of character education materials in schools should be based on and should use Indonesian cultural background. This finding is also in line with Rosjidan (2015) saying that efforts to develop character education in Indonesia should incorporate elements of national cultural values into the basic concepts of learning character education in schools.

\section{Conclusion}

Grounded in the discussion above, some of the main things in this study can be summed up as follows.

a) Philosophy contains the purpose, function, and principles of learning character education in schools, especially for the Bimanese. The definition of Philosophy, in general, is the advice, teachings or precept, mandate, or will or exhortation of the kings of Bima, wise people, prominent figures, parents which are inherited from generation to generation to their citizens. The aim of philosophy is to advise children, grandchildren, family/relatives. The philosophy function is divided into two: preventive and corrective. Preventive functions in the form of personal approaching to children, grandchildren, and family/relatives. Correctively, the philosophy serves to advise citizens who make mistakes not to do the same thing in the future. The philosophy principle is as follows; (1) Philosophy must be given to people who disagree and reconcile it, (2) Old community figures must not allow protracted mistakes because they are the ones who bear the

b) Philosophical Value contains the learning content of character education in schools, especially those related to the objective component of having self-awareness: The values of Nggahi Poda and Rombo Ade are included in the objective component of having self-awareness; the value of Nggahi Poda dan rombo ade included in the component that develops a positive attitude; the values of Kacoi Angi and Tahompara Nahu Sura Dou Marimpa are included in the objective component of being able to respect others; the values of Nggahi Poda, Rombo Ade, Tenggo and Nggahi Rawi Pahu are included in the objective component with responsibility; the value of rundu, Kacoi Angi, and Tohompara Nahu Sura Dou Marimpa is included in the component of objectives to develop inter-personal relations; the value of Nggahi Poda, Rombo Ade, Rundu, Kacoi Angi, Tahompara nahu sura dou marimpa and Wii Weki ndei Ruma are included in the objective component to resolve conflicts; the value of Nggahi Poda, rombo ade dan wii weki ndai Ruma is included in the objective component of making good choices; and the value of nggahi poda, rombo ade, tenggo and wii weki ndai Ruma is included in the objective component to make good decisions.

Based on the results of the analysis of the study, it is recommended that: (1) The counselors and teachers as educators in schools need to include the philosophy values as one of the material in character education materials, (2) This research only reveals the concepts and values of community cultural philosophy in Bima community for the development of learning material for character building only, then the next researcher needs to conduct as a study related to the development of learning and career, and (3) the Government and school counselors then need to develop a character education learning service package in schools containing the values of the Philosophy of Maja Labo Dahu.

Mustamin, -, \& Junaidin, -. (2018). Local wisdom philosophy of labo maja dahu for bima community. International Journal of Social Sciences and Humanities, 2(3), 33-44. https://doi.org/10.29332/ijssh.v2n3.194 
Acknowledgments

The accomplishment of this research cannot be realized without the guidance and assistance given by various parties. On this occasion, I would like to thank and respect all parties who have provided assistance and support in the completion of this research. 
References

Aziz, Y. A., Sari, I. P., Kusumasari, N., Sari, N. F., \& Putri, I. H. (2016). Usaha pengenalan warisan budaya surakarta kepada generasi muda melalui merchandise "addorable stuff".

Endraswara, S. (2015). Kajian Budaya Religi dan Ritual. Studi Religi dan Ritual Antro, Teguh Imam Prasetyo (ed). Accesses, 21.

Gepu, W., Suda, I. K., \& Suyasa, I. M. (2018). Religious conversion towards Hindu Kaharingan to Christianity. International Journal of Linguistics, Literature and Culture, 4(4), 25-37.

Hadi, N. (2017). Menggali nilai-nilai pendidikan karakter berwawasan kebangsaan dari tradisi "kasada" pada masyarakat tengger, di kantong taman nasional bromo-tengger-semeru.

Hardianta, I. K. S., Sudiatmaka, K., \& Sanjaya, D. B. (2015). Identifikasi Nilai-nilai Pendidikan Karakter Pada Tradisi Makepung Sebagai Sumber Belajar PPKn Di SMP N 4 Mendoyo (studi kasus di Desa Pakraman Delod Berawah Kecamatan Mendoyo, Kabupaten Jembrana, Bali). Jurnal Pendidikan Kewarganegaraan Undiksha, 3(1).

Harianja, J., \& Waluyo, T. J. (2017). Upaya United Nations Educational, Scientific and Cultural Organization (Unesco) Dalam Menjaga Keberadaan Museum Sangiran Sebagai Warisan Budaya Dunia Tahun 2011-2016. Jurnal Online Mahasiswa Fakultas Ilmu Sosial dan Ilmu Politik Universitas Riau, 5(1), 1-10.

Jasman, J. (2017). Implementasi Nilai-Nilai Kearifan Lokal Dalam Pengembangan Pariwisata Budaya Di Kabupaten Bima. Jurnal Administrasi Negara, 14(3).

Jonker,J.C.G. (1983). Bima Neesche Texten

Komensky, A. M. (1980). The federal government may attempt to enter the malpractice arena with the health care protection act of 1979. CAL [magazine] Certified Akers Laboratories, 44(4), 15-21.

Krippendorff, K. (1986). Information theory: structural models for qualitative data (Vol. 62). Sage.

Munandir, J. A. B., \& Luth, T. (2017). Tanggung jawab notaris atas akta pernyataan keputusan rapat. Jurnal Cakrawala Hukum, 8(1), 55-63. Nurhasanah, N. (2017). Makna Simbolik Uma Lengge Bagi Masyarakat Tradisional Sambori Kecamatan Lambitu Kabupaten Bima. Jurnal Ilmiah Mandala Education (JIME), 3(1), 201-209.

Pinasti, V. I. S., \& Lestari, P. Masyarakat samin ditinjau dari sejarah dan nilai-nilai pendidikan karakter. Istoria: Jurnal Pendidikan dan Ilmu Sejarah, 13(2).

RIJAL, S. (2016). Pengetahuan Lokal Pemanfaatan Satuan Lingkungan Oleh Masyarakat Desa Sambori Kabupaten Bima. NTB (Doctoral dissertation, University of Muhammadiyah Malang).

Rosjidan, M. A. (2006). Pengantar Konseling.

Shartzer, A., Long, S. K., \& Anderson, N. (2015). Access to care and affordability have improved following Affordable Care Act implementation; problems remain. Health Affairs, 35(1), 161-168.

Shihab, M. Q. (1996). Wawasan al-Qur'an. Bandung: Mizan, 1419.

Soekarno. (1959). Di Bawah Bendera Revolusi, Dijilid I dan II, Djakarta.

Subagiasta, I. K., \& Dharmika, I. B. (2018). Shifting on Usik Liau game in Wara ceremony towards Hindu Kaharingan society of Dayak Dusun. International Research Journal of Management, IT and Social Sciences, 5(4), 98-105.

Wirawan, I. W. A. (2018). Maintaining Social Relationship of Balinese and Sasak Ethnic Community. International Journal of Social Sciences and Humanities (IJSSH), 2(1), 92-104.

Mustamin, -, \& Junaidin, -. (2018). Local wisdom philosophy of labo maja dahu for bima community. International Journal of Social Sciences and Humanities, 2(3), 33-44. https://doi.org/10.29332/ijssh.v2n3.194 


\section{Biography of Authors}

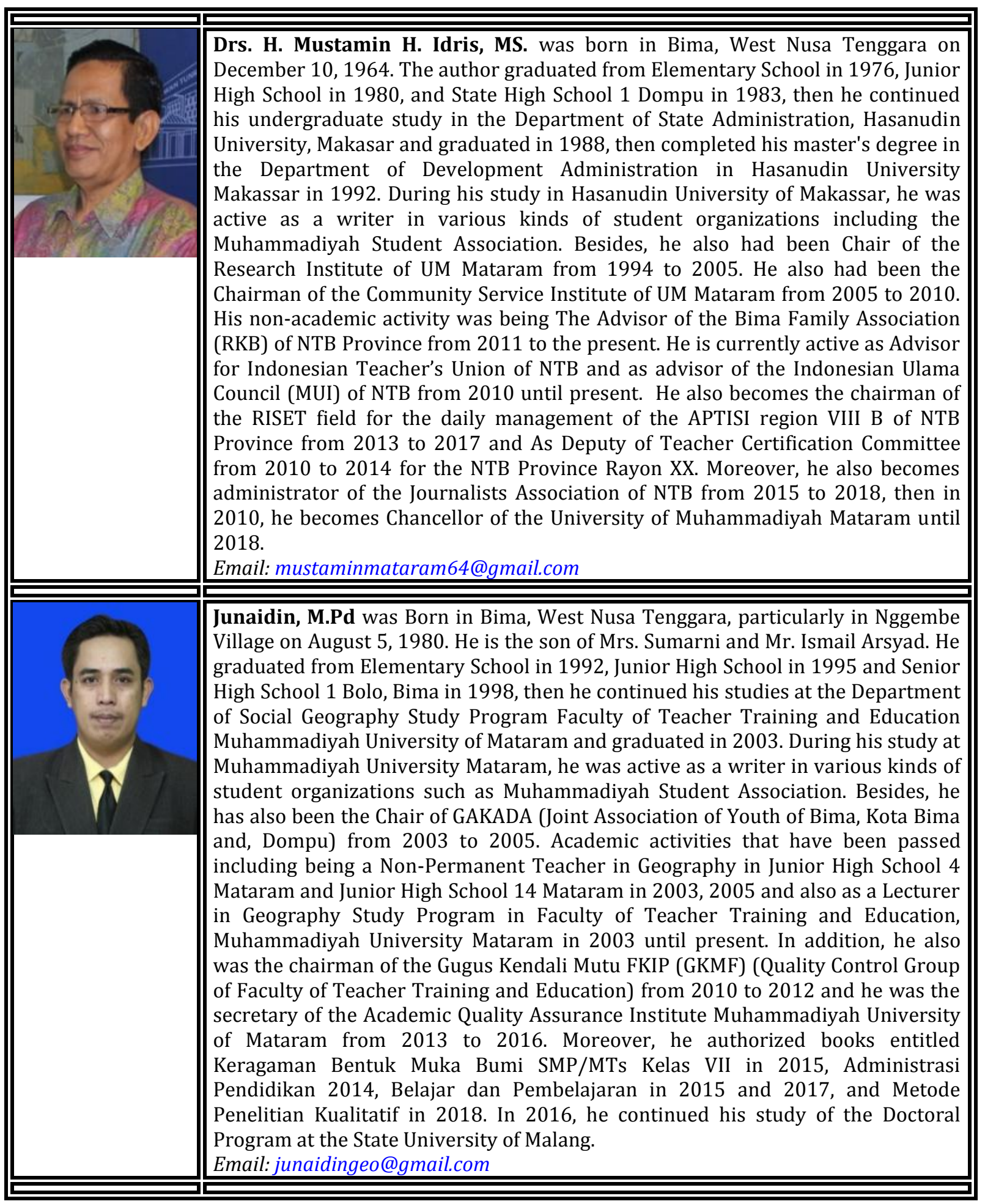

